\title{
A poorly known case of watershed transposition between the São Francisco and upper Paraná river basins
}

\author{
Orlando Moreira Filho* and Paulo Andreas Buckup**
}

During construction of the Furnas hydroelectric power dam in the upper rio Paraná basin in the early 1960s, the rio Piumhi drainage outflow was diverted into the headwaters of the São Francisco river basin. The rio Piumhi was a right bank tributary of the rio Grande, which unites with the rio Paranaíba to form the rio Paraná. The transposition allowed the entire fish fauna of the rio Piumhi and associated swamps, lakes, and tributaries to intermingle with the fish fauna of the São Francisco basin via the ribeirão Sujo, a right bank tributary of the São Francisco. The transposition of the watershed may have had a major impact on the current composition of the fish fauna of the upper rio São Francisco watershed.

Durante a construção do reservatório hidroelétrico de Furnas na bacia do alto rio Paraná no início da década de 1960, o fluxo de águas do rio Piumhi foi desviado para as cabeceiras da bacia do rio São Francisco. O rio Piumhi era um tributário da margem direita do rio Grande, o qual se une com rio Paranaíba para formar o rio Paraná. A transposição permitiu que toda a fauna de peixes do rio Piumhi e banhados, lagos e tributários associados se mesclasse com a fauna de peixes da bacia do rio São Francisco através do ribeirão Sujo, um tributário da margem direita do São Francisco. A transposição da bacia pode ter ocasionado grande impacto na atual composição da fauna de peixes da bacia do alto rio São Francisco.

Key words: River transposition.

Headwater stream capture between watersheds is a phenomenon of major interest for biogeographers. In the Neotropical Region, for example, stream capture has been proposed as a possible explanation for the distribution of the characid Mimagoniates microlepis in the headwaters of the rio Iguaçu in the plains around Curitiba on the west side of the Serra do Mar (Weitzman et al., 1988). On the other hand, artificial watershed transposition projects have been a source of controversy among scientists and governmental agencies (e.g. Izique, 2005). In Brazil, the impact of artificial river transposition on the fish fauna has been poorly documented. Hydroelectric power systems transposing large volumes of waters in the Atlantic Rainforest areas of the Serra do Mar are relatively well known. They include the transfer of waters from the rio Paraíba do Sul drainage into the coastal rio Guandu system, and from the upper Tietê headwaters into the adja- cent coastal systems. Although the effects of these transfers on the fish fauna are poorly known, one can safely assume that they have been restricted to relatively small coastal drainages, which previously had a relatively low fish diversity. Here we report on the rio Piumhi transposition, which constitutes an instance of artificial river transposition that, unlike the previous examples, may have had a major impact on the two largest river systems of eastern Brazil: the São Francisco and the Paraná basin. Despite its potential impact on the ichthyofauna, the event apparently went unnoticed by the majority of ichthyologists working on the taxonomy of fishes from these areas. The Piumhi transposition is not mentioned in recent reviews of the composition of the ichthyofauna of the São Franscisco basin (e.g., Bristki et al., 1986) and its headwater streams (e.g. Casatti \& Castro, 1997). Alves \& Pompeu (2001) listed six species that were artificially intro-

\footnotetext{
*Dept. de Genética e Evolução, Universidade Federal de São Carlos, via Wasgington Luiz km 235, Cx. Postal 676, 13565-905 São Carlos, SP, Brasil. e-mail: omfilho@power.ufscar.br

**Dept. de Vertebrados, Museu Nacional, Universidade Federal do Rio de Janeiro, Quinta da Boa Vista, 20940-040 Rio de Janeiro, RJ, Brasil. e-mail: buckup@acd.ufrj.br
} 


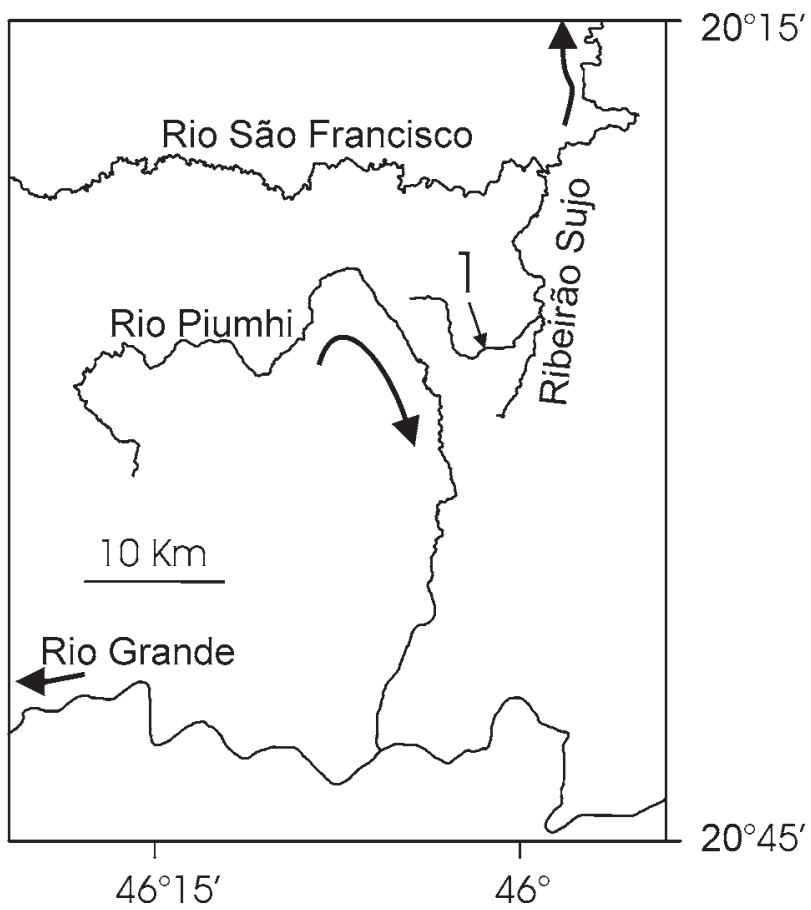

Fig. 1. Rio Piumhi prior to the construction of the Furnas Hydroelectric Dam. The Ribeirão da Água Limpa is indicated by the number 1 .

duced in the rio das Velhas watershed, but did not consider river transposition among possible sources of introductions. The transposition is not mentioned in recent reviews of fish diversity in the upper Paraná (Castro \& Menezes, 1998) and inventories of the rio Grande drainage (Castro \& Casatti, 1997; Castro et al., 2004).

The headwaters of the rio Piumhi are located between the cities of Vargem Bonita and Piumhi, in the middle west of the Minas Gerais State, in Brazil, at 930 m of elevation. Before 1963 the stream was a right-bank tributary of the rio Grande, which, along with the rio Paranaíba, comprises the source of the rio Paraná, the main watershed draining southern Brazil, Paraguay, and northern Argentina. The stream flowed initially towards the Northeast, performing a clockwise turn until it reached the rio Grande, flowing southward downstream of Capitólio, at about $760 \mathrm{~m}$ of elevation (Fig. 1). Part of its course traversed over $38 \mathrm{~km}$ of a large swamp, known as the Pantanal do Piumhi. Some of its tributaries (da Onça, Mutuca, do Servo, Campão Grande, do Fumo, and Capão da Olaria creeks) did not connect with the main river course, but flowed into the large Pantanal area.

The rio Piumhi drainage transposition was prompted by the construction of the Furnas Hydroelectric Power Dam in the rio Grande, between July 1958 and September 1963, when the first turbine started to operate. The Furnas Hydroelectric Power Dam is located between the cities of São José da Barra and São João Batista in Minas Gerais State, with a maximum height of $127 \mathrm{~m}$. The lake formed by the dam has a minimum operation level of $750 \mathrm{~m}$ above sea level and may reach a

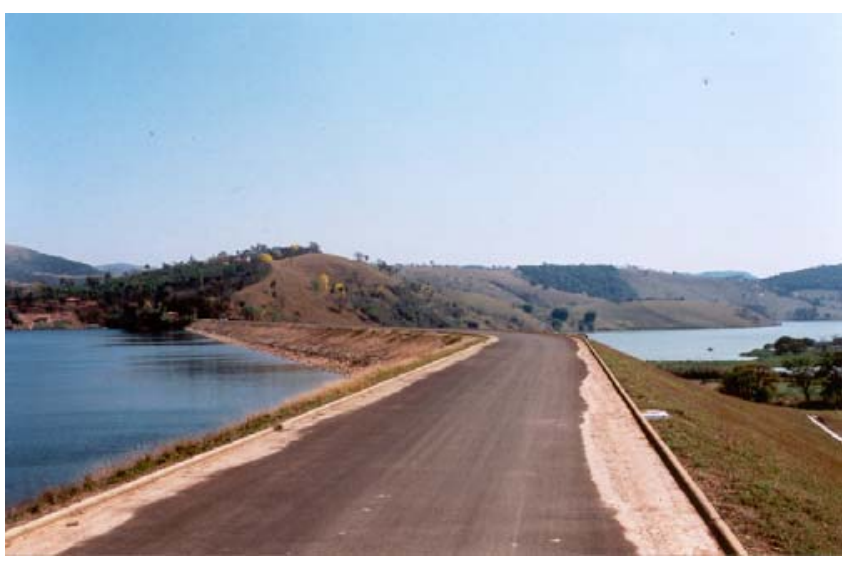

Fig. 2. Capitólio dam. The Furnas artificial lake is seen on the left side, and the lake formed by the damming of the rio Piumhi waterflow is seen on the right side.

maximum flood level of $769.30 \mathrm{~m}$. Filling the lake required the building of a secondary dam (Fig. 2) to avoid flooding the city of Capitólio and spilling the waters into the nearby rio São Francisco system through the ribeirão Sujo, a right bank tributary of the São Francisco. However, the construction of this secondary dam isolated the rio Piumhi drainage on January 9,1963 , which at the time was a right bank tributary of the rio Grande mainstream. Therefore, the waters of the Piumhi were transferred through a system of about $18 \mathrm{~km}$ of artificial canals to the córrego Água Limpa, a left bank tributary of the ribeirão Sujo. This essentially meant that the Piumhi watershed, with its associated marginal lakes and 22 tributaries, was severed from the Paraná-Plata system and became an integral part of the São Francisco system.

The hydroelectric project had a major impact on the configuration of the aquatic environments. The water flow in the lower segment of the Piumhi, in front of Capitólio, was reversed. The southern portion located next to the dam turned into a stagnant lake, and the northern portion drained into an artificial canal (Fig.3) that connected with the main canal leading to the córrego Água Limpa. The córrego Água Limpa and portions of the ribeirão Sujo were dredged and rectified and the water volume was greatly increased by the inflow from the Piumhi. The most significant environmental impact was the draining of the large swamp which was originally associated with the Piumhi and covered about 20.000 ha. The deviation canal (Fig. 4) was cut several meters below the original river bed, thus draining the surrounding swamps and even the river bed downstream from its connection with the new canal. The ancient Pantanal do Piumhi was drained and turned into farmland. The hydrologic changes and the destruction of riparian vegetation in the Piumhi drainage resulted in a major increase in sediments being transported into the ribeirão Sujo watershed and the pilling up of large banks of sediment near its mouth in the São Francisco.

All these changes certainly had a major impact on the aquatic biota, but most are fairly localized in the sense that they affected only the Piumhi region. However, we would 


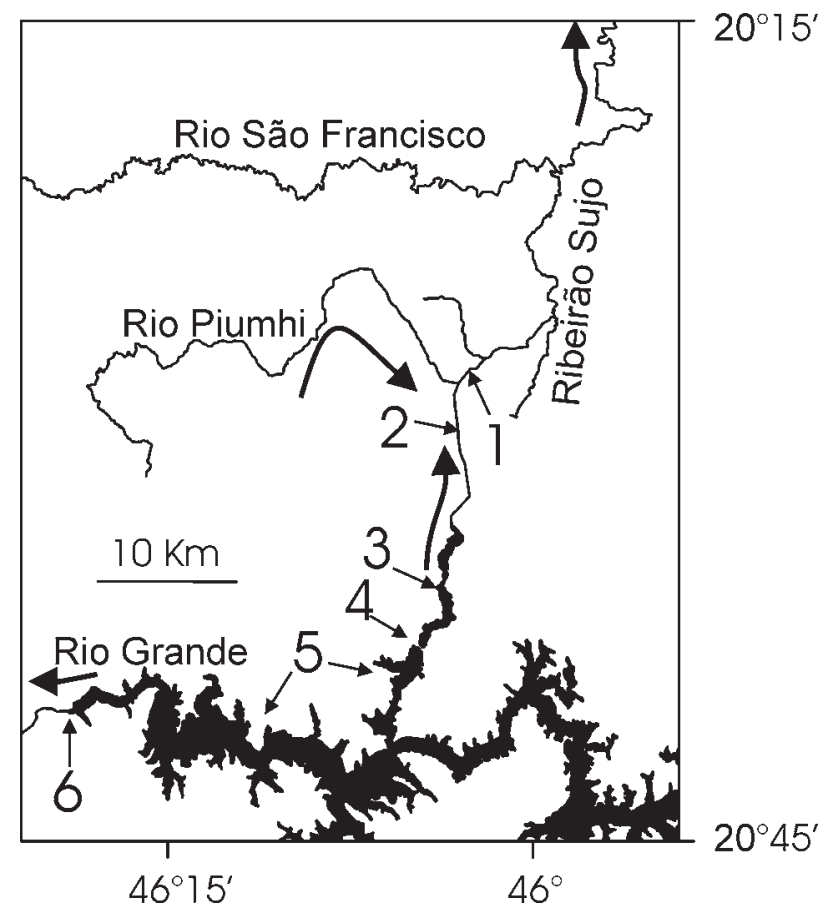

Fig. 3. Piumhi watershed transposition: (1) transposition canal, (2) canal for reversed flow from remnants of lower Piumhi drainage, (3) artificial lake formed at lower Piumhi drainage after construction of Capitólio dam, (4) Capitólio dam, (5) Furnas lake, formed by the Furnas Hydroelectric Dam, (6) Furnas Dam on the rio Grande.

like to call the attention of our colleagues to a much more significant impact that may involve the entire São Francisco system, namely the possibility of permanent alteration of the composition of the São Francisco aquatic biota. Based on the lack of references to this event in the systematic and biogeographic literature in the last four decades, it appears that the transposition of the Piumhi and its entire ichthyofauna went unnoticed by the majority of the systematists studying São Francisco and upper Paraná fishes.

The importance of the Piumhi event for biodiversity studies becomes evident if one considers that it is unlikely that the drainage of the ribeirão Sujo is currently capable of maintaining the sum of the species occurring in its original watershed plus the entire fish fauna originally occurring in the Piumhi watershed. When the two faunas were forced into coexistence through the interconnection of the watersheds it is likely that some species would be led to extinction though competition, predation, and hybridization. On the other hand it is likely that those species that survive will eventually become invasive organisms in the host drainage. This is particularly important for migratory species such as Leporinus octofasciatus, which we have recently collected in the transposition canal. That species is native to the upper Paraná system, but is now present in the São Francisco watershed.

Although the bulk of the faunal transfer was directed from the Paraná to the São Francisco system, we cannot entirely rule out the possibility that some species from the São Fran-

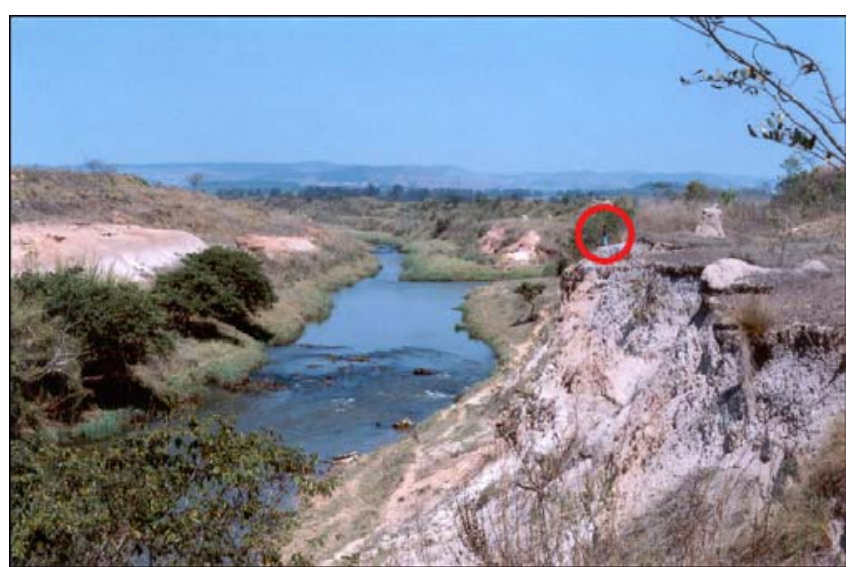

Fig. 4. Transposition canal (foreground) connecting rio Piumhi (formerly part of Paraná system) and Ribeirão da Água Limpa (São Francisco System), downstream from junction of artificial canals draining upper course (right) and reversed lower course (background) of rio Piumhi. Relative height of excavation may be estimated from size of adult person standing on top of left bank (indicated by red circle).

cisco may have dispersed upstream during the construction of the canals and have reached the rio Grande drainage prior to the final closing of the Capitólio Dam.

We suggest that such a significant event of faunal interchange should be taken into consideration in future biodiversity studies involving either the upper Paraná or the São Francisco systems. Menezes (1970:75) suggested that the swamp areas located in the western headwaters of the São Francisco in the state of Goiás were the origin of the great faunal similarity between the São Francisco and Paraná systems that was detected at that time. Most of the data used by Menezes (1970) were based on studies conducted prior to the 1963 transposition of the Piumhi swamp, and the faunal similarity may have a Pleistocene or earlier origin. Current estimates of faunal similarity, however, should take into consideration the possibility of major biases caused by the artificial interconnection of Pantanal do Piumhi and the São Francisco drainage. To provide data for further studies the fish fauna currently inhabiting the Piumhi and the adjacent drainages is being studied by the research teams at the Universidade Federal de São Carlos and the Museu Nacional of the Universidade Federal do Rio de Janeiro.

\section{Literature Cited}

Alves, C.B.M. \& Pompeu, P.S. 2001. A fauna de peixes da bacia do rio das Velhas no final do Século XX. Pp.165187. In: Alves, C.B.M. \& Pompeu, P.S. (Org.). Peixes do rio das Velhas: passado e presente. Belo Horizonte, SEGRAC, 194p.

Britski, H.A., Y. Sato \& A.B.S. Rosa. 1986. Manual de identificacao de peixes da região de Três Marias (com chaves de identificação para os peixes da bacia do São Francisco). 2.ed. Brasilia, CODEVASF, 115p. 
Casatti, L. \& R.M.C. Castro. 1998. A fish community of the São Francisco river headwaters riffles, southeastern Brazil. Ichthyol. Explor. Freshwaters 9(3):229-242.

Castro, R.M.C. \& Casatti, L. 1997. The fish fauna from a small forest stream of the upper Paraná river basin, southeastern Brazil. Ichthyol. Explor. Freshwaters, 7(4):337-352.

Castro, R.M.C.; Casatti, L.; Santos, F.H.; Melo, A.L.A.; Martins, L.S.F.; Ferreira, K.M.; Gibran, F.Z.; Benine, R.C.; Carvalho, M.; Ribeiro, A.C.; Abreu, T.X.; Bockmann, F.A.; Pelição, G.Z.; Stopiglia, R.; Langeani, F. 2004. Estrutura e composição da ictiofauna de riachos da bacia do Rio Grande no Estado de São Paulo, Sudeste do Brasil. Biota Neotropica, 4(1):1-39.

Izique, C. As águas vão rolar; transposição do rio São Francisco divide opiniões e instiga polêmica entre governo e pesquisadores. Pesquisa FAPESP, 112: 26-29.

Menezes, N.A. 1970. Distribuição e origem da fauna de peixes de água doce das grandes bacias fluviais do Brasil. Pp.7378. In: Comissão Interestadual da Bacia Paraná-Uruguai. Poluição e piscicultura; notas sobre poluição, ictiologia e piscicultura. São Paulo, Faculdade de Saúde Pública da USP, Secretaria da Agricultura, Instituto de Pesca, 216p.
Weitzman, S.H.; Menezes, N.A.; Weitzman, M.J. 1988. Phylogenetic biogeography of the Glandulocaudini (Teleostei: Characiformes, Characidae) with comments on the distributions of other freshwater fishes in Eastern and Southeastern Brazil. Pp.379427. In: Vanzolini, P.E. \& Heyer, W.R. (Eds.) Proceedings of a workshop on neotropical distribution patterns. Rio de Janeiro, Academia Brasileira de Ciências, 488p.

Received July 2005 Accepted September 2005 